\begin{tabular}{|l|l|l||}
\hline \multicolumn{2}{|c|}{ PublisherInfo } \\
\hline \hline PublisherName & $:$ & BioMed Central \\
\hline \hline PublisherLocation & $:$ & London \\
\hline \hline PublisherImprintName & $:$ & BioMed Central \\
\hline \hline
\end{tabular}

\title{
Regulation of anergy-related genes in RA T cells
}

\begin{tabular}{||l|l|l||}
\hline \multicolumn{2}{|c|}{ ArticleInfo } \\
\hline \hline ArticleID & $:$ & 102 \\
\hline \hline ArticleDOI & $:$ & $10.1186 /$ ar-2001-68052 \\
\hline \hline ArticleCitationID & $:$ & 68052 \\
\hline \hline ArticleSequenceNumber & $:$ & 59 \\
\hline \hline ArticleCategory & $:$ & Paper Report \\
\hline \hline ArticleFirstPage & $:$ & 1 \\
\hline \hline ArticleLastPage & $:$ & 4 \\
\hline \hline & & RegistrationDate : 2001-5-17 \\
& $:$ & Received \\
ArticleHistory & & Accepted 2001-7-25 \\
& $: 2001-7-25$ \\
\hline \hline ArticleCopyright & $:$ & Biomed Central Ltd2001 \\
\hline \hline ArticleGrants & $:$ & \\
\hline \hline
\end{tabular}




\begin{tabular}{|l|l|l||}
\hline ArticleContext & $: 130753311$ \\
\hline
\end{tabular}

Patrick Costello, ${ }^{\text {Aff1 }}$

Aff1 St Vincent's University Hospital, Dublin, Ireland

\section{Keywords}

\section{Context}

Rheumatoid arthritis (RA) T cells share many features with anergic T cells. This study analysed changes in gene transcription in a T-cell during antigen-induced anergy and examined levels of anergyassociated transcripts in RA.

\section{Significant findings}

A total of 55 different cDNA sequences were identified, which formed the basis of an array used to confirm differential gene expression and compare transcription in RA and reactive arthritis $(\operatorname{ReA})$ synovium. Of these sequences, 22 corresponded to known genes, the remainder being expressed sequence tags (ESTs), 20 of which gave no database match. Of the 55 cDNA sequences, 25 were anergy related transcripts, 11 being expressed in synovial tissues. Eight of these synovial transcripts were equally transcribed or upregulated in RA compared to ReA: PMA-ionophore-linked activation factor of $\mathrm{T}$ cells, T plastin, calumenin, eukaryotic elongation factor 1-d, ADP ribosylation-like factor-1, aortic carboxypeptidase-like protein and the ESTs BF626660 and BF626663. The three remaining transcripts were downregulated in RA: calmodulin, a calcium-binding protein that regulates other calciumdependent proteins (100-fold lower); cellular apoptosis susceptibility protein (CAS) was fourfold lower; and the EST BF626661 was 10-fold lower. Calmodulin and BF626661 were downregulated in anergic T cells while CAS was not. Lower expression of calmodulin and CAS was confirmed in individual biopsies by real-time PCR. Calmodulin and BF626661 were downregulated in synovial fluid mononuclear cells compared with peripheral blood mononuclear cells. Anti-TNF-a therapy upregulated calmodulin transcription but not CAS transcription, while inhibiting calmodulin blocked antigeninduced proliferation. 


\section{Comments}

The upregulation of calmodulin following infliximab treatment and the induction of anergy following calmodulin inhibition links the hyporesponsiveness of RA T cells to calmodulin expression. Calmodulin is a ubiquitous calcium-sensing protein, which is central to the regulation of signal transduction. T-cell hyporesponsiveness in arthritis has been linked to alterations in intracellular calcium (iCa) responses, which fail to transfer activating signals (see Additional information [1]). More recently Carruthers et al (see Additional information [2]) have demonstrated abnormalities in the magnitude, pattern and spatial distribution of $\mathrm{iCa}$ signaling in synovial fluid $\mathrm{T}$ cells. Hence, reduced calmodulin expression may magnify the inability of $\mathrm{T}$ cells to transfer activating signals. The observed hyporesponsiveness, however, is also affected by decreased intracellular glutathione, a decreased tyrosine phosphorylation pattern and diminished phosphorylation of the TCR ?-chain (see Additional information [3,4]). These results suggest that defective TCR signaling may contribute to the hyporesponsive nature of synovial $\mathrm{T}$ cells. While this is a preliminary study with a low sample number the data presented shed new light on the cellular defects observed in RA.

\section{Methods}

RNA extraction and cDNA generation, differential display RT-PCR, T-cell culture, differential hybridisation, northern blot

\section{Additional information}

1. Allen ME, Young SP, Michell RH, Bacon PA: Altered T lymphocyte signaling in rheumatoid arthritis. Eur J Immunol 1995, 25:1547-1554 (<a href="http://neptune.nlm.nih.gov/entrez/ query.fcgi? $\mathrm{cmd}=$ Retrieve $\& \mathrm{db}=$ PubMed\&list_uids $=7614981 \&$ dopt $=$ Abstract" $>$ PubMed abstract $</ a>$ ).

2. Carruthers DM, Arrol HP, Bacon PA, Young SP: Dysregulated intracellular $\mathrm{Ca}^{+}{ }^{+}$stores and $\mathrm{Ca}^{+}$signaling in synovial fluid $\mathrm{T}$ lymphocytes from patients with chronic inflammatory arthritis.

Arthritis Rheum 2000, 43:1257-1265 (<a href="http://neptune.nlm.nih.gov/entrez/ query.fcgi?cmd=Retrieve \&db=PubMed\&list_uids=10857784\&dopt=Abstract"target="new" $>$ PubMed abstract $</ a>$ ). 
3. Maurice MM, Nakamura H, van der Voort EA, van Vliet, AI, Staal FJ, Tak PP, Breedveld FC, Verweij CL: Evidence for the role of an altered redox state in hyporesponsiveness of synovial $T$ cells in rheumatoid arthritis.

J Immunol 1997, 158:1458-1465 (<a href="http://neptune.nlm.nih.gov/entrez/ query.fcgi? $\mathrm{cmd}=$ Retrieve \&db=PubMed\&list_uids=9013992\&dopt=Abstract"target="new" $>$ PubMed abstract $</ a>$ ).

4. Maurice MM, Lankester AC, Bezemer AC, Geertsma MF, Tak PP, Breedveld FC, van Lier RA, Verweij CL: Defective TCR-mediated signaling in synovial $\mathrm{T}$ cells in rheumatoid arthritis.

J Immunol 1997, 159:2973-2978 (<a href="http://neptune.nlm.nih.gov/entrez/ query.fcgi?cmd=Retrieve \&db=PubMed\&list_uids=9300721\&dopt=Abstract"target="new" $>$ PubMed abstract $</ a>$ ).

\section{References}

1. Ali M, Ponchel F, Wilson KE, Francis MJ, Wu X, Verhoef A, Boylston AW, Veale DJ, Emery P, Markham AF, Lamb JR, Isaacs JD: Rheumatoid arthritis synovial T cells regulate transcription of several genes associated with antigen-induced anergy. J Clin Invest. 2001, 107: 519-528.

This PDF file was created after publication. 